\title{
AKTUALISASI SASU'U SALEMBA DALAM PEMBAGIAN WARISAN MASYARAKAT BIMA
}

\author{
Zuhrah, Juhriati, Husntaul Mahmudah \\ STIH Muhammadiyah Bima \\ Jalan Anggrek No.16 Ranggo Na'e Kota Bima \\ Email:zuhrah@stihm-bima.ac.id \\ Email:juhriati@stihm-bima.ac.id \\ Email:arraynez@gmail.com
}

\section{Abstrak}

Secara umum di Indonesia belum terbentuk unifikasi hukum waris. Terlihat dari pluralitas hukum waris yang digunakan oleh masyarakat tanpa adanya sanksi bila memakai salah satu hukum waris tersebut (hukum waris Islam, hukum waris Perdata dan hukum Waris Adat).

Dari sisi teologi, masyarakat muslim berkeinginan membagi warisan sesuai dengan kaidah al-Quran dan Sunnah. Akan tetapi, karena kurangnya pengetahuan masyarakat akan pembagian warisan secara Islam menyebabkan masyarakat membagi sesuai kehendak mereka. Lembaga peradilan yang menangani kewarisan hanya terbatas pada lingkup sengketa saja, tidak memberi edukasi bagaimana membagi warisan secara Islam. Masalah ini yang dihadapi masyarakat Bima saat ini dan entah sampai kapan akan berlanjut.

Sasu'u Salemba dipahami sebagai metode pembagian warisan secara Islam dan dianggap telah dilaksanakan oleh masyarakat Bima. Padahal dalam kenyataannya bahwa pembagian warisan masyarakat Bima berdasarkan asas musyawarah mufakat. Dimana konteks tersebut menunjukkan bahwa jargon Sasu'u Salemba tinggal teori 
masa lalu bagi masyarakat Bima, bukan lagi dogma yang dipercaya sebagai bawaan agama yang harus dijalankan.

\section{Keywords: Sasu'u Salemba, Warisan, Masyarakat Bima}

\section{Pendahuluan}

Sebagaimana kita ketahui bahwa sistem hukum waris yang berlaku di Indonesia ada tiga, yakni sistem hukum waris Islam, Adat dan sistem hukum waris perdata. Sistem hukum waris Islam didasarkan pada al-Quran surat an-Nisa ayat 11-12, sistem hukum waris adat didasarkan pada bentuk etnis di berbagai daerah lingkungan hukum adat tertentu, dan sistem kewarisan perdata didasarkan pada KUHPerdata yang merupakan warisan dari Belanda. ${ }^{1}$

Pewaris, ahli waris dan harta warisan merupakan unsur integralistik dalam pembagian warisan, baik secara Islam, Keperdataan maupun adat. Dalam perspektif Islam, harta warisan merupakan jumlah total harta bawaan (apabila disepakati untuk menjadi harta warisan) dan harta bersama setelah dikurangi untuk keperluan pewaris selama sakit, biaya pengurusan jenazah, pembayaran hutang serta wasiat pewaris.

Dalam sistem kewarisan Islam terdapat lima asas yakni asas ijbari, asas bilateral, asas individual, asas keadilan berimbang dan asas semata akibat kematian. Asas-asas tersebut memiliki filosofi tersendiri dalam konteks pembagian waris Islam. Akan tetapi, dari lima asas tersebut tidak terlaksana secara masif oleh masyarakat sehingga selalu menjadi teori semata.

Permasalahan dalam pembagian waris Islam semakin komplek.

1. Ketidakpahaman masyarakat akan siapa yang menjadi pewaris dan ahli waris. Karena yang menjadi pewaris tidak selalu orang

${ }^{1}$ Zuhrah, "Hukum Waris di indonesia Dalam Pandangan Hazairin," 37.

Sangaji Jurnal Pemikiran Syariah dan Hukum 
tua, akan tetapi jika yang meninggal lebih dahulu sang anak maka dari harta anak tersebut ada hak waris orang tua. Pun demikian dengan ahli waris, tidak harus selalu sang anak yang menjadi ahli waris. Tetapi orang tua ketika meninggal lebih belakangan maka mereka adalah ahli waris dari anaknya. Hal ini mengacu kepada asas semata akibat kematian, dimana penenetuan siapa yang menjadi pewaris dan ahli waris adalah siapa yang meninggal terlebih dahulu baru bisa diketahui antara pewaris dan ahli waris.

2. Pembagian warisan disaat masih hidup. Masih mengacu pada asas hukum waris Islam yakni asas semata akibat kematian, karena apabila harta dibagi saat hidup, maka disebut hibah. Masyarakat berpandangan bahwa terjadinya pembagian warisan disaat pewaris masih hidup adalah untuk menghindari konflik antar ahli waris yang satu dengan ahli waris lainnya.

3. Penentuan bagian untuk anak laki-laki dan perempuan yang tidak sesuai dengan aturan Islam dimana penerjemahannya dalam bahasa Bima yakni Sasu'u Salemba. Masalah ketiga pembagian waris dalam masyarakat Bima mengacu pada asas musyawarah mufakat masyarakat, dimana bagian untuk anak bisa sama besar atau besar dan kecil, tergantung hasil kesepakatan dan kebiasaan masing-masing daerah.

4. Perampasan harta waris oleh yang tidak berwenang mendapatkan harta warisan tersebut dan permasalahan ini sangat beragam, diantaranya: pertama, seorang paman yang mengambil harta kemenakannya dimana sang paman masih terhalang oleh ahli waris utama; kedua, saudara yang mengambil hak saudara lainnya. Padahal masing-masing saudara tersebut telah dibagi sesuai dengan hak mereka.

5. Peruntukkan harta warisan untuk dinikmati bersama yang disebabkan oleh terbatasnya harta warisan orang tua dan keinginan para ahli waris untuk tidak menghilangkan harta dari orang tua dan ingin diabadikan sebagai kenangan. Sebagai 
contoh, orang tua meninggalkan ahli waris lima orang dan meninggalkan harta warisan berupa tanah satu petak saja. Sehingga tanah tersebut digarap dan dinikmati bersama hasilnya, bukan lagi membagi waktu untuk dinikmati oleh masing-masing individu. Dalam asas hukum waris Islam disebutkan bahwa dalam peruntukkan harta untuk masingmasing ahli waris.

Tetapi dalam penulisan ini penulis hanya fokus pada aktualisasi pembagian warisan Sasu'u Salemba pada masyarakat Bima yang semakin hari ditinggalkan. Munculnya permasalahan tersebut tidak lepas dari tanggung jawab pemerintah yakni lembaga peradilan yang menangani kewarisan, tokoh agama maupun tokoh masyarakat. Bila direview kembali, bahwa masyarakat masa kini dan masa lalu sangat jauh berbeda. Bila pada masa awal masuknya Islam, masyarakat akan mengadukan masalah pembagian warisan mereka pada Badan Hukum Syara' untuk dimintai pertimbangan dan Badan Hukum Syara' akan memberi arahan bahwa harta mana yang harus menjadi harta warisan dan mana yang tidak. ${ }^{2}$ Pada masa sekarang, masyarakat bahkan tabu membicarakan pembagian warisan apabila ada orang tua atau sang anak yang memiliki harta meninggal dunia. Hal itu dianggap sebagai manusia pragmatis atau jahiliyah, yang tidak mengenal kondisi berkabung membicarakan masalah harta waris.

Jargon Sasu'u Salemba yang tertanam di alam bawah sadar masyarakat tidak lagi menjadi penuntun untuk pembagian warisan masyarakat Bima. Hal ini seiring dengan perkembangan pola pikir masyarakat dengan melihat bahwa anak adalah sama, atau melihat siapa anak yang paling berperan dalam mengurus orang tuanya maka bagiannya akan banyak atau siapa yang paling banyak menghabiskan harta orang tua maka bagiannya akan berkurang. Masalah pembagian warisan dengan metode Sasu'u

2 Murtadha dan Mutawali, "IMPLEMENTASI HUKUM ISLAM DI KESULTANAN BIMA," 10.

Sangaji Jurnal Pemikiran Syariah dan Hukum 
Salemba penting dikemukakan untuk mengubah cara pembagian warisan masyarakat Bima dengan menggunakan metode masingmasing untuk kembali menerapkan Sasu'u Salemba yang menjadi hukum Tuhan yang sifatnya pasti dan adil. Di samping itu, dari penelusuran penulis bahwa pembahasan tentang waris cukup banyak tapi tidak spesifik pada permaslahan pembagian warisan Sasu'u Salemba pada Masyarakat Bima.

Jainuddin menulis tentang Pembagian Waris Pada Masyarakat Bima ditinjau Dari Aspek Sosiologi Hukum. ${ }^{3}$ Penelitian tersebut mendeskripsikan bahwa masyarakat Bima membagi warisan berdasarkan Hukum Islam dan juga atas kesepakatan bersama. Tetapi tidak disebutkan berapa persentase masyarakat yang membagi waris Islam dan juga yang membagi dengan kesepakatan bersama. Pun tidak dijelaskan apakah pembagian waris Islam tersebut berdasarkan perhitungan Islam dimana laki-laki memiliki bagian lebih besar dari perempuan yang selalu diistilahkan dengan Sasu'u Salemba atau metode kesepakatan bersama seperti apa yang diimplementasikan oleh masyarakat Bima.

Jainuddin juga menulis tentang Pembagian Harta Warisan: Telaah Pembagian Warisan Oleh Pewaris Kepada Ahli Waris Sebelum Pewaris Meninggal Pada Masyarakat Bima. ${ }^{4}$ Penelitian ini mendeskripsikan tentang pembagian warisan yang dilakukan pada saat pewaris (orang tua) masih hidup merupakan adat turun temurun masyarakat Bima untuk menghindari konflik dan menunjang kebutuhan ekonomi anak-anaknya.

Dari segi orisinalitas, tulisan tentang Aktualisasi Sasu'u Salemba Dalam Pembagian Warisan Masyarakat Bima tidak

3 Jainuddin, "PEMBAGIAN WARIS PADA MASYARAKAT BIMA DI TINJAU DARI ASPEK SOSIOLOGI HUKUM," 126.

${ }^{4}$ Jainuddin, "PEMBAGIAN HARTA WARISAN; TELAAH PEMBAGIAN WARISAN OLEH PEWARIS KEPADA AHLI WARIS SEBELUM PEWARIS MENINGGAL PADA MASYARAKAT BIMA," 298. 
memiliki kesamaan dengan tulisan sebelumnya. Tulisan ini akan mendeskripsikan dan mengevaluasi tentang aktualisasi Sasu'u Salemba yang diterapkan masyarakat Bima dan apa faktor sehingga menyebabkan masyarakat Bima tidak mengatualisasikan Sasu'u Salemba dalam pembagian warisan.

\section{Metode Penelitian}

Penulisan ini menggunakan metode survey sebagai instrumen penulisan yang merupakan bentuk aktifitas yang sudah menjadi kebiasaan masyarakat ilmiah. (Hukum dan Studi Penelitian,) Sedangkan pendekatan yang digunakan adalah pendekatan sosiologi. ${ }^{5}$ yakni mengamati perilaku sosial masyarakat yang dinamis, dimana pada masa lalu masyarakat Bima menggunakan metode pembagian warisan Sasu'u Salemba. Tetapi kini telah terjadi pergeseran paradigma tentang pembagian warisan Sasu'u Salemba yang dianggap merupakan cara pembagian warisan masyarakat jaman dahulu.

\section{Hasil dan Pembahasan}

\section{Asas Hukum Waris Islam}

Berbicara tentang hukum selalu memiliki asas. Pun demikian dengan hukum waris Islam, tidak lepas dari asas yang berfungsi sebagai kaidah kritis terhadap aturan hukum. Adapun asas-asas hukum kewarisan Islam yang dimaksud adalah: ${ }^{6}$

1. Asas Ijbari

Secara etimologis kata ijbari mengandung arti paksaan (compulsory), yaitu melakukan sesuatu di luar kehendak sendiri. Dalam hal hukum waris berarti terjadinya peralihan harta seseorang yang telah meninggal dunia kepada yang masih hidup dengan sendirinya, maksudnya tanpa ada perbuatan hukum atau pernyataan kehendak dari si pewaris, bahkan si

5 “Abintoro_SOSIOLOGI HUKUM.pdf," 49.

${ }^{6}$ K. Lubis dan Simanjuntak, Hukum Waris Islam, 39-40.

Sangaji Jurnal Pemikiran Syariah dan Hukum 
pewaris (semasa hidupnya) tidak dapat menolak atau menghalang-halangi terjadi peralihan tersebut.

Dengan perkataan lain, dengan adanya kematian si pewaris secara otomatis hartanya beralih kepada ahli warisnya, tanpa terkecuali apakah ahli warisnya suka menerima atau tidak (demikian juga halnya bagi si pewaris).

Asas ijbari ini dapat dilihat dari beberapa segi, yaitu:

a. Dari segi peralihan harta;

b. Dari segi jumlah harta yang beralih

c. Dari segi kepada siapa harta beralih.

Ketentuan asas ijbari ini dapat dilihat antara lain dalam ketentuan QS. An-Nisa ayat 7 yang menjelaskan bahwa bagi seseorang laki-laki maupun perempuan ada nasib dari harta peninggalan orang tua dan karib kerabatnya. Kata nasib dalam ayat tersebut dapat berarti saham, bagian, atau jatah dari harta peninggalan si pewaris.

2. Asas Bilateral

Adapun yang dimaksud dengan asas bilateral dalam hukum kewarisan Islam adalah bahwa seseorang menerima hak warisan dari kedua belah pihak garis kerabat, yaitu dari garis keturunan perempuan maupun garis keturunan laki-laki. Asas bilateral ini secara tegas dapat ditemui dalam ketentuan QS. An-Nisa ayat 7, 11, 12, dan 176. Antara lain dalam ayat 7 dikemukakan bahwa seorang laki-laki berhak memperoleh warisan dari pihak ayahnya dan demikian juga dari pihak ibunya. Begitu pula seorang perempuan mendapat warisan dari kedua pihak orang tuanya.

Asas bilateral ini juga berlaku pula untuk kerabat garis ke samping (yaitu melalui ayah dan ibu).

3. Asas Individual

Pengertian asas individual ini adalah setiap ahli waris (secara individu) berhak atas bagian yang didapatnya tanpa terikat kepada ahli waris lainnya (sebagaimana halnya dengan 
pewarisan kolektif yang dijumpai di dalam ketentuan hukum Adat).

Dengan demikian, bagian yang diperoleh ahli waris dari harta pewaris dimiliki secara perorangan, dan ahli waris yang lainnya tidak ada sangkut paut sama sekali dengan bagian yang diperolehnya tersebut, sehingga individu masing-masing ahli waris bebas menentukan (berhak penuh) atas bagian yang diperolehnya.

Ketentuan asas individual ini dapat dijumpai dalam ketentuan QS. An-Nisa ayat 7 yang mengemukakan bahwa masing-masing (ahli waris secara individual) telah ditentukan.

4. Asas Keadilan Berimbang

Asas keadilan berimbang maksudnya adalah keseimbangan antara hak dan kewajiban dan keseimbangan antara yang diperoleh dengan keperluan dan kegunaan.

Dengan perkataan lain dapat dikemukakan bahwa faktor jenis kelamin tidaklah menentukan dalam hak kewarisan (kebalikan dari asas keseimbangan ini dijumpai dalam masyarakat yang menganut sistem garis keturunan patrilineal, yang ahli waris tersebut hanyalah keturunan laki-laki saja/garis kebapakan). Dasar hukum asas ini dapat dijumpai antara lain dalam ketentuan QS. An-Nisa' ayat 7, 11, 12, dan 176.

5. Kewarisan Semata Akibat Kematian

Hukum waris Islam memandang bahwa terjadinya peralihan harta hanya semata-mata akibat kematian. Dengan perkataan lain, harta seseorang tidak dapat beralih (dengan pewarisan) seandainya dia masih hidup. Walaupun ia berhak untuk mengatur hartanya, hak tersebut semata-mata hanya sebatas keperluannya semasa ia masih hidup, dan bukan untuk penggunaan harta tersebut sesudah ia meninggal dunia. Dengan demikian, hukum waris Islam tidak mengenal seperti yang ditemukan dalam ketentuan hukum waris menurut Kitab 
Undang-Undang Hukum Perdata (BW), yang dikenal dengan pewarisan secara $a b$ intestato dan secara testamen.

\section{Makna Sasu'u Salemba}

Secara historis masuknya Islam di Bima sekitar abad XV melalui pedagang yang datang dari Jawa. ${ }^{7}$ Pelembagaan Peradilan Islam yang dikenal dengan Mahkamah Syar'iyyah yang menangani bidang masalah pencatatan perkawinan, perceraian, pendidikan, kewarisan, wakaf, dakwah, penentuan hari besar Islam, pelaksana kegiatan-kegiatan keagamaan, dan mengurus keberangkatan dan kepulangan jama'ah haji dari Bima berlaku pada tanggal 14 Agustus $1788 .^{8}$ Artinya bahwa pemberlakuan warisan secara Islam di Bima dimulai sejak pelembagaan peradilan Islam.

Istilah Sasu'u Salemba sebenarnya bukan istilah yang baru muncul atau istilah daerah yang tidak memiliki makna dalam bahasa Indonesia secara umum, hanya saja istilah tersebut diterjemahkan dalam bahasa Bima. Jika dalam Islam dikenal dengan istilah 2:1 (baca: dua berbanding satu), lalu diterjemahkan dalam bahasa Bima yakni Sasu'u Salemba (Sejunjung Sepikul) adalah bagian laki-laki sepikul yang artinya 2 (dua) dan sejunjung yang artinya 1 bagi perempuan. Sehingga makna Sasu'u Salemba bukanlah bahasa daerah yang memiliki nilai adat atau makna tertentu.

Dasar hukum penentuan bagian untuk laki-laki dan perempuan yang menetapkan angka 2:1 dalam pembagian warisan atau Sasu'u Salemba dalam bahasa Bima berangkat dari QS An-Nisa ayat 11 yang berbunyi "Allah mensyariatkan (mewajibkan) kepadamu tentang (pembagian warisan untuk) anak-anakmu, (yaitu) bagian seorang anak laki-laki sama dengan bagian dua orang anak perempuan. (Tentang) 195.

7 Salahuddin, "MAHKAMAH SYAR'IYYAH DI KESULTANAN BIMA," 8 Salahuddin, 196. 
orang tuamu dan anak-anakmu, kamu tidak mengetahui siapa di antara mereka yang lebih banyak manfaatnya bagimu". Menurut Muhammad Amin Suma bahwa ayat tersebut disamping sebagai ayat penentuan hak pasti bagi ahli waris laki-laki dan perempuan, juga mengingatkan jangan sampai meninggalkan anak keturunan yang lemah materi, ini sangat mungkin yang dimaksudkan adalah juga rahasia pembagian harta warisan yang menganut perimbangan 2:1 bagi laki-laki dan perempuan. Bagi anak laki-laki telah dipersiapkan sama dengan dua bagian anak perempuan mengingat anak laki-laki yang masih kecil itu sudah "dibayangbayangi" beban keluarga kelak begitu dia dewasa yang ditandai dengan pintu gerbang perkawinan. Sementara anak-anak perempuan, sama sekali tidak digelayuti oleh beban kewajiban untuk menafkahi keluarga, yang ada malah sebaliknya, ia/mereka (anak-anak perempuan) boleh jadi sudah menggadang-gadang akan mendapatkan pemberian mahar dan nafkah dari para suaminya. Di sinilah terletak rahasia ayat yang menyatakan, "Kalian (manusia) sama sekali tidak mengetahui betul, siapa diantara mereka yang akan lebih banyak/besar manfaatnya dengan ketentuan pembagian harta kewarisan yang seperti itu". ${ }^{9}$

\section{Aktualisasi Sasu'u Salemba Dalam Pembagian Warisan}

Sebagai daerah yang kental keislamannya, Bima menganut sistem Sasu'u Salemba perihal pembagian warisan. Sasu'u Salemba itu sendiri merupakan sistem pembagian waris Islam yang diadopsi masyarakat Bima dari al-Quran yang menetapkan 2 berbanding 1 bagi ahli waris. Tetapi dalam aktualisasinya saat ini tidak demikian, seiring dengan pergeseran paradigma masyarakat dan juga minimnya pengetahuan masyarakat tentang pembagian warisan secara Islam. Sehingga dari dari hasil penelitian yang

${ }^{9}$ Suma, "Menakar Keadilan Hukum Waris Islam Melalui Pendekatan Teks dan Konteks al-Nushûsh."

Sangaji Jurnal Pemikiran Syariah dan Hukum 
dilakukan bahwa telah terjadi pluralisme pembagian warisan dalam tatanan hidup masyarakat Bima.

Pertama, aktualisasi pembagian warisan masyarakat Bima adalah dengan musyawarah mufakat dimana orang tua sebagai pewaris membagi warisan kepada anak-anaknya sesuai dengan hasil musyawarah mufakat yakni: 1) anak laki-laki dan perempuan mendapat bagian yang sama besar karena kedudukan mereka sebagai anak; 2) anak pertama mendapat bagian lebih besar daripada anak selanjutnya. Kedudukan anak tersebut bisa laki-laki atau perempuan, karena anggapan mereka bahwa anak pertama adalah penerus dan pengganti orang tua jikalau orang tua sudah tidak ada dan anak pertama tersebut berkewajiban mengurus adikadiknya. Fenomena ini terjadi pada beberapa daerah di Bima dan dilakukan secara turun temurun; 3) bagi anak yang telah menghabiskan harta lebih banyak terlebih dahulu maka bagian warisnya akan berkurang, baik digunakan untuk hal-hal baik maupun tidak baik tetap diperhitungkan. Laki-laki maupun perempuan diperlakukan sama.

Kedua, jika dilihat dari teori hukum Islam Munawir Sadzali masalah kewarisan bahwa pembagian warisan masyarakat Bima diberikan kepada anak baik laki-laki maupun perempuan dengan bagian yang sama besar tetapi dengan syarat bahwa anak perempuan memiliki peran. Pengertian peran disini adalah anak perempuan yang mengurus orang tuanya ketika masih hidup. Peran ini dinilai oleh orang tua sebagai pewaris karena konteks pembagian waris masyarakat Bima yakni ketika orang tua masih hidup. Bahwa anak yang setia mengurus orang tua diberi bagian yang lebih besar dengan pertimbangan telah menghabiskan banyak energi untuk mengurus orang tua bahkan ada anak yang tidak menikah karena fokus mengurus orang tua. Bagi orang tua yang menilai anak-anaknya yang mengurus mereka merasa tidak adil bila menerapkan Sasu'u Salemba terhadap anak perempuan yang punya peran dibandingkan dengan anak laki-laki yang abai. 
Ketiga, keluarga atau orang tua yang tidak memberikan hak waris kepada salah satu atau lebih anaknya dikarenakan faktor ketidakpatuhan anak terhadap orang tua. Misalnya sang anak berjudi, minum-minuman keras, tidak patuh pada perintah orang tua, tidak memperhatikan orang tua ketika sakit (abai terhadap orang tua) dan lain-lain. Hal tersebut dijadikan pertimbangan untuk tidak diberikan hak waris kepada anak, padahal dari segi hal yang menghalangi warisan bukan hal-hal yang disebutkan di atas tetapi lebih kepada dua hal spesifik yang disebutkan dalam hadis yakni pembunuhan dan murtad.

Peristiwa ketiga berbeda dengan peristiwa kedua dimana peristiwa ketiga tidak memberi sama sekali kepada anak yang dianggap tidak patuh kepada kedua orang tua baik laki-laki maupun perempuan. Sedangkan peristiwa kedua tetap memberi hak kepada anak laki-laki maupun anak perempuan tetapi dengan bagian yang sama besar apabila punya peran.

Faktor Tidak Teraktualisasinya Sasu'u Salemba dalam Pembagian Warisan Masyarakat Bima

Dalam kontekstualisasi pembagian warisan masyarakat Bima ditemukan faktor yang menyebabkan tidak teraktualisasinya sistem Sasu'u Salemba pada masyarakat Bima, diantaranya:

1. Disamping ketidakpahaman dengan sistem pembagian waris Islam, para orang tua berpandangan bahwa Sasu'u Salemba adalah metode pembagian warisan orang tua jaman dahulu, bukan metode pembagian waris yang diadopsi dari Islam. Sehingga metode tersebut tidak diaktualisasi oleh masyarakat Bima khususnya masyarakat awam.

2. Tidak adanya sosialisasi dari tokoh agama baik yang berada pada instansi pemerintahan (kelembagaan) maupun tokoh agama yang ada dalam masyarakat umum yang memiliki pengetahuan tentang tata cara pembagian warisan Islam sehingga semakin memunahkan pengetahuan masyarakat akan

Sangaji Jurnal Pemikiran Syariah dan Hukum 
pentingnya pembagian warisan Islam yang disebut $S a s u^{\prime} u$ Salemba dalam masyarakat Bima. Bila direview bahwa Pengadilan Agama hanya mengambil bagian untuk penyelesaian sengketa waris, tetapi bukan bersifat mengedukasi atau mensosialisasikan tentang tata cara membagi waris secara Islam.

3. Terjadi kemajuan berpikir masyarakat terutama masyarakat berpendidikan yang menganggap bahwa Sasu'u Salemba sudah tidak relevan lagi dengan masa sekarang karena dianggap tidak adil bagi kaum perempuan. Hal ini sejalan dengan teori Hukum Islam Munawir Sadzali tentang kontekstualisasi hukum Islam yang mengkritisi QS An-Nisa ayat (11) yang membagi warisan terhadap laki-laki dan perempuan adalah 2:1. Munawir Sadzali menginginkan perubahan terhadap aturan tersebut dimana laki-laki dan perempuan mendapat bagian yang sama yakni 1:1. Inilah yang terjadi dalam masyarakat Bima saat ini yang membagi warisan kepada anak laki-laki dan anak perempuannya sama besar.

4. Sikap apatis masyarakat terhadap pembagian warisan secara Islam, sehingga menganggap bahwa hukum agama setara dengan hukum yang dibuat manusia. Ini bermakna bahwa hukum yang dibuat oleh siapapun termasuk hukum agama bisa dilanggar tanpa memikirkan konsekuensi dari pelanggaran tersebut.

\section{Simpulan}

Dari penelusuran penulis tentang aktualisasi Sasu'u Salemba dalam pembagian warisan masyarakat Bima adalah terungkapnya metode pembagian warisan masyarakat Bima yang plural dimana terjadi berbagai macam sudut pandang masyarakat pada masalah pembagian warisan dan menganggap bahwa Sasu'u Salemba adalah metode pembagian warisan orang tua jaman dulu sehingga tidak relevan lagi dengan generasi saat ini. 


\section{Daftar Pustaka}

“Abintoro_SOSIOLOGI HUKUM.pdf," t.t.

Jainuddin, Jainuddin. "PEMBAGIAN HARTA WARISAN;

TELAAH PEMBAGIAN WARISAN OLEH PEWARIS

KEPADA AHLI WARIS SEBELUM PEWARIS

MENINGGAL PADA MASYARAKAT BIMA." SANGAJI:

Jurnal Pemikiran Syariah dan Hukum 4, no. 2 (26 September 2020): 298-313. https://doi.org/10.52266/sangaji.v4i2.494.

- - - "PEMBAGIAN WARIS PADA MASYARAKAT BIMA DI TINJAU DARI ASPEK SOSIOLOGI HUKUM." SANGAJI: Jurnal Pemikiran Syariah dan Hukum 3, no. 1 (22 Maret 2019): 125-44. https://doi.org/10.52266/sangaji.v3i1.457.

K. Lubis, Suhrawardi, dan Komis Simanjuntak. Hukum Waris Islam. 2 ed. Jakarta: Sinar Grafika, 2013.

Murtadha, Rahmah, dan Muhammad Mutawali. "IMPLEMENTASI HUKUM ISLAM DI KESULTANAN BIMA." Preprint. Open Science Framework, 28 Oktober 2017. https://doi.org/10.31219/osf.io/58kgz.

Salahuddin, Muh. "MAHKAMAH SYAR'IYYAH DI KESULTANAN BIMA: WUJUD DIALEKTIKA HUKUM ANTARA ISLAM DAN ADAT." ULUMUNA 9, no. 1 (10 Juni 2005): 189. https://doi.org/10.20414/ujis.v9i1.451.

Suma, Muhammad Amin. "Menakar Keadilan Hukum Waris Islam Melalui Pendekatan Teks dan Konteks al-Nushûsh." AHKAM: Jurnal Ilmu Syariah 12, no. 2 (7 Agustus 2012). https://doi.org/10.15408/ajis.v12i2.965.

Zuhrah, Zuhrah. "Hukum Waris di indonesia Dalam Pandangan Hazairin." Fundamental 3 (2014).

Sangaji Jurnal Pemikiran Syariah dan Hukum 